\title{
XXIII OGÓLNOPOLSKA KONFERENCJA FOTOINTERPRETACJI I TELEDETEKCJI
}

W dniach 24-25 września 2018 roku na Wydziale Nauk Geograficznych Uniwersytetu Łódzkiego odbyła się XXIII Ogólnopolska Konferencja Fotointerpretacji i Teledetekcji. Organizatorami Konferencji były: Oddział Teledetekcji i Geoinformatyki Polskiego Towarzystwa Geograficznego, Sekcja Teledetekcji Komitetu Badań Kosmicznych i Satelitarnych PAN oraz Zakład Geoinformacji Wydziału Nauk Geograficznych Uniwersytetu Łódzkiego. XXIII OKFiT, zorganizowana pod hasłem „Współczesna Teledetekcja w Badaniach Środowiska Geograficznego”, była jednym z wydarzeń związanych ze 100-leciem Polskiego Towarzystwa Geograficznego. W dwudniowych obradach wzięło udział 80 osób (z trzech krajów) reprezentujących 25 różnych uczelni i firm z całej Polski oraz jedną uczelnię z Niemiec. W czasie konferencji wygłoszonych zostało 40 referatów oraz zaprezentowano 19 posterów. Streszczenia wszystkich prac zamieszczono w wydanym w związku z tym wydarzeniem Okólniku TD nr 138 (wersja cyfrowa: https://ptgeo. org.pl/wp-content/uploads/2018/09/OK-138.pdf).

Konferencja rozpoczęla się krótkimi wystąpieniami przypominającymi początki badań teledetekcyjnych w naszym kraju, poprzednie Ogólnopolskie Konferencje Fotointerpretacji i Teledetekcji, a także działalność Oddziału Teledetekcji i Geoinformatyki PTG. W referatach pierwszej sesji omawiano także m.in. przyszłość nauczania teledetekcji w Polsce i na świecie, nowe rozwiązania przetwarzania i udostępniania oraz oceny jakości danych geoprzestrzennych, aktualne trendy w sektorze kosmicznym, w tym program realizowany przez Polską Agencję Kosmiczną POLSA, a także nowe algorytmy przetwarzania satelitarnych danych wieloczasowych oraz koncepcję funkcjonowania platformy EOcloud. Dalsze obrady pierwszego dnia Konferencji odbyły się w dwóch równoległych sesjach. W jednej dominowały zagadnienia dotyczące rozpoznawania i analizy 
stanu roślinności w rolnictwie i leśnictwie, natomiast druga sesja była zdominowana przez zagadnienia związane $\mathrm{z}$ badaniami stanu atmosfery. Obrady drugiego dnia prowadzone były najpierw w dwóch równoległych sesjach. W jednej w zasadzie kontynuowano zagadnienia dotyczące detekcji roślinności, w drugiej natomiast dominowały referaty dotyczące analizy wód na obszarach mokradeł, w rzekach, zalewach i jeziorach, a także w Morzu Bałtyckim. Wspólna sesja końcowa została przeznaczona na referaty wprowadzające do tematyki warsztatów, podsumowanie konferencji oraz opublikowanie wyników konkursów. Stwierdzono, że teledetekcja w naszym kraju rozwija się dynamicznie, a okolicznościami sprzyjającymi są rozwój platform teledetekcyjnych (od bezzałogowych statków powietrznych po rozbudowane konstelacje systemów satelitarnych), wyraźnie zwiększona dostępność danych wielokanałowych (zobrazowania hiperspektralne) oraz radarowych, nowe metody przetwarzania danych, a także możliwości korzystania z algorytmów i mocy obliczeniowych oferowanych przez wyspecjalizowane podmioty (przechowywanie danych i ich przetwarzanie w tzw. „chmurach”). Dostępność bezpłatnych danych satelitarnych NASA i ESA staje się czynnikiem rozwoju porównywalnym do tego, jaki uzyskano po udostępnieniu systemu pozycjonowania satelitarnego GPS i dalszych.

W trakcie konferencji przeprowadzono trzy konkursy o „Złoty Piksel” - nagrodę ustanowioną przez Oddział Teledetekcji i Geoinformatyki PTG. Laureatem konkursu na najlepszy referat został Andrzej Kotarba z Centrum Badań Kosmicznych PAN (referat pod tytułem „Pionowe zróżnicowanie zachmurzenia ogólnego nad Polską na podstawie jednoczesnych obserwacji satelitarnych lidaru CALIOP i radaru CloudSat"). Konkurs na najlepszą pracę magisterską z zakresu teledetekcji wygrała Anita Sabat-Tomala za pracę „Zastosowanie danych hiperspektralnych Hyspex do badania jakości wód Jeziora Zegrzyńskiego", napisaną na Uniwersytecie Warszawskim pod kierunkiem Anny Jarocińskiej, natomiast laureatem konkursu na najlepszą pracę wykorzystującą dane programu Copernicus został Piotr Wężyk z Wydziału Leśnego Uniwersytetu Rolniczego w Krakowie za referat „Przeskalowywanie informacji ze zintegrowanych chmur punktów ULS i TLS w metodzie automatycznej detekcji zniszczeń lasu na obrazach Dove (Planet) oraz Sentinel-2 (ESA) w Borach Tucholskich".

Ważnym elementem konferencji były cztery tematyczne warsztaty przeprowadzone przez: Instytut Badawczy Leśnictwa (,Naziemne pomiary hiperspektralne” oraz „Przetwarzanie danych z lotniczego skanowania laserowego w środowisku R”), firmę ProGea 4D („PlanetLabs - badaj nieustannie zmieniający się świat. Wprowadzenie do teledetekcji satelitarnej na podstawie zobrazowań Planet”) oraz Hexagon Geospatial (,Tworzenie modeli przetwarzania danych dla geoprocesów działających w chmurze - Smart M.apps firmy Hexagon”). 
Uczestnicy konferencji mieli także możliwość poznać fragment dynamicznie zmieniającej się Łodzi podczas pieszej wycieczki „Łódź [od]nowa”. Tytuł wycieczki nawiązywał do zakrojonego na niespotykaną skalę i realizowanego już programu rewitalizacji szeroko rozumianej tkanki miejskiej.

Wsparcia dla Konferencji w różnej formie udzielili: ESRI Polska (Warszawa), Hexagon Geospatial (Łódź), Instytut Badawczy Leśnictwa (Sękocin Stary), InvestGIS (Kraków), ProGea 4D (Kraków) oraz Urząd Miasta Łodzi.

Dr hab. inż. Krzysztof Będkowski, prof. UŁ Mgr inż. Adam Bielecki Dr Marcin Jaskulski

Zakład Geoinformacji Instytut Geografii Miast i Turyzmu Wydział Nauk Geograficznych Uniwersytet Łódzki e-mail: krzysztof.bedkowski@geo.uni.lodz.pl e-mail: adam_biel@o2.pl e-mail: marcin.jaskulski@geo.uni.lodz.pl 